\title{
PENGARUH PENAMBAHAN GLISEROL TERHADAP SIFAT KEKUATAN TARIK DAN PEMANJANGAN SAAT PUTUS BIOPLASTIK DARI PATI UMBI TALAS
}

\author{
Rinaldi Febrianto Sinaga, Gita Minawarisa Ginting, M. Hendra S Ginting, Rosdanelli Hasibuan \\ Departemen Teknik Kimia, Fakultas Teknik, Universitas Sumatera Utara, \\ Jl. Almamater Kampus USU, Medan 20155, Indonesia \\ Email : naldi_sinaga@yahoo.co.id
}

\begin{abstract}
Abstrak
Bioplastik adalah salah satu jenis plastik yang terbuat dari sumber biomassa terbarukan, seperti minyak nabati, pati jagung, pati kacang polong, dan mikrobiota. Pati dari umbi talas (Colocasia esculenta) berpotensi sebagai bahan baku pembuatan bioplastik dengan menggunakan gliserol sebagai plastizicer. Tujuan dari penelitian ini adalah mengetahui pengaruh penambahan gliserol terhadap sifat kekuatan tarik dan pemanjangan saat putus bioplastik dari pati umbi talas. Pada penelitian ini, pembuatan bioplastik menggunakan metode casting dengan variasi larutan pati $(0,2$ $\mathrm{w} / \mathrm{v}, 0,3 \mathrm{w} / \mathrm{v}$, dan $0,4 \mathrm{w} / \mathrm{v})$. Selanjutnya dilakukan variasi penambahan volume gliserol $(1 \% \mathrm{v}$, $2 \% \mathrm{v}$, dan $3 \% \mathrm{v})$ dan temperatur pemanasan pembentukan gelatin $\left(60^{\circ} \mathrm{C}, 70^{\circ} \mathrm{C}\right.$, dan $\left.80^{\circ} \mathrm{C}\right)$. Hasil penelitian menunjukkan bahwa bioplastik berbahan baku pati umbi talas memiliki temperatur gelatinisasi $70^{\circ} \mathrm{C}$. Penambahan volume gliserol berpengaruh terhadap nilai kekuatan tarik dan pemanjangan saat putus dari bioplastik yang dihasilkan. Seiring bertambahnya volume gliserol maka nilai kekuatan tarik akan semakin menurun, sebaliknya nilai pemanjangan saat putus akan semakin meningkat. Bioplastik terbaik pada penelitian ini adalah bioplastik variasi pati $0,3 \mathrm{w} / \mathrm{v}$, penambahan $1 \%$ v gliserol pada temperatur $70^{\circ} \mathrm{C}$ yang menghasilkan kekuatan tarik 18,4992 MPa dan nilai pemanjangan saat putus $2,1290 \%$.
\end{abstract}

Kata kunci : pati, talas, bioplastik, gliserol.

\begin{abstract}
Bioplastics are a type of plastic made from renewable biomass sources, such as vegetable oil, corn starch, pea starch, and microbiota. Starch from tubers of talas (Colocasia esculenta) as a potential raw material for bioplastics by using glycerol as plastizicer. The purposes of the research are to know effect of adding glycerol to the properties of tensile strength and elongation at break bioplastic from starch taro tubers. In this research, the manufacture of bioplastics using casting methode with variations of starch solution $(0,2 \mathrm{w} / \mathrm{v}, 0,3 \mathrm{w} / \mathrm{v}$, and $0,4 \mathrm{w} / \mathrm{v})$. The next additions to vary the volume of glycerol $(1 \% v, 2 \% v$, and $3 \% v)$ and heating temperature of gelatin formation $\left(60^{\circ} \mathrm{C}, 70^{\circ} \mathrm{C}\right.$, and $\left.80^{\circ} \mathrm{C}\right)$. The results showed that bioplastics made from taro tuber starch has gelatinization temperature of $70^{\circ} \mathrm{C}$. The addition of glycerol volume effect value of tensile strength and elongation at break of bioplastics. Increasing volume of glycerol will decrease tensile strength but increase elongation at break value. The best of bioplastics in this research is a variation of starch bioplastic $0,3 \mathrm{w} / \mathrm{v}$, addition of $1 \% \mathrm{v}$ glycerol at a temperature of $70^{\circ} \mathrm{C}$ with a value of tensile strength is $18,4992 \mathrm{MPa}$ and elongation at break value is $2,1290 \%$.
\end{abstract}

Keywords : starch, taro, bioplastic, glycerol

\section{Pendahuluan}

Pengunaan plastik sedemikian meluasnya bahkan karena sangat tinggi tingkat ketergantungan padanya sehingga hampir-hampir sudah tidak dapat terpisahkan dari kehidupan keseharian kita, tidak terkecuali untuk kemasan makanan [11]. Penggunaan plastik sebagai bahan pengemas menghadapi berbagai persoalan lingkungan, yaitu sulitnya didaur ulang, dan tidak dapat diuraikan secara alami oleh mikroba di dalam tanah, sehingga terjadi penumpukan sampah plastik yang menyebabkan pencemaran dan kerusakan lingkungan. Seperti diketahui, plastik konvensional butuh 500 - 1000 tahun untuk terurai dalam tanah. Sulitnya penguraian ini membuat sampah plastik semakin menumpuk dan menyebabkan pencemaran dan kerusakan lingkungan [1].

Untuk menyelamatkan lingkungan dari bahaya plastik, saat ini telah dikembangkan bioplastik, artinya plastik yang dapat diuraikan kembali oleh mikroorganisme secara alami menjadi senyawa yang ramah lingkungan yang berasal dari selulosa, pati, kolagen, kasein, protein atau lipid yang terdapat dalam hewan. Kandungan pati yang berasal dari umbi talas 
yang cukup tinggi memungkinkan digunakan sebagai bahan pembuat bioplastik.

Tujuan dari penelitian ini adalah untuk mengetahui bagaimana pengaruh penambahan gliserol terhadap sifat kekuatan tarik dan pemanjangan saat putus bioplastik.

\section{Teori}

Bioplastik merupakan plastik yang dapat digunakan layaknya seperti plastik konvensional, namun akan hancur terurai oleh aktivitas mikroorganisme menjadi hasil akhir air dan gas karbondioksida setelah habis terpakai dan dibuang ke lingkungan. Karena sifatnya yang dapat kembali ke alam, bioplastik termasuk bahan plastik yang ramah terhadap lingkungan [9].

Talas dengan nama latin Colocasia esculenta merupakan tanaman umbi-umbian berupa herba menahun [10]. Pati merupakan komponen karbohidrat utama di dalam umbi talas. Kandungan pati pada umbi talas dapat dilihat pada tabel 1 berikut ini [14].

Tabel 1. Kandungan Pati pada Umbi Talas [14]

\begin{tabular}{|l|c|}
\hline \multicolumn{1}{|c|}{ Komponen } & $\begin{array}{c}\text { Komposisi } \\
(\mathrm{g} \text { pati/100g talas })\end{array}$ \\
\hline Kadar air (g/100g) & 10,20 \\
\hline Protein $(\mathrm{g} / 100 \mathrm{~g})$ & 12,25 \\
\hline Lemak (g/100 g) & 0,50 \\
\hline Abu (g/100 g) & 4,15 \\
\hline Serat kasar $(\mathrm{g} / 100 \mathrm{~g})$ & 0,75 \\
\hline Karbohidrat $(\mathrm{g} / 100 \mathrm{~g})$ & 72,15 \\
\hline Pati (g/100 g) & 67,42 \\
$\bullet$ Amilosa (g/100 g) & 2,25 \\
$\bullet$ Amilopektin $(\mathrm{g} / 100 \mathrm{~g})$ & 65,17 \\
\hline
\end{tabular}

Plasticizer berfungsi untuk meningkatkan elastisitas dengan mengurangi derajat ikatan hydrogen dan meningkatkan jarak antar molekul dari polimer. Semakin banyak penggunaan plasticizer maka akan meningkatkan kelarutan. Begitu pula dengan penggunaan plasticizer yang bersifat hidrofilik juga akan meningkatkan kelarutannya dalam air. Gliserol memberikan kelarutan yang lebih tinggi dibandingkan sorbitol pada bioplastik berbasis pati [3]. Gliserol juga merupakan plasticizer yang efektif karena memiliki kemampuan untuk mengurangi ikatan hidrogen internal pada ikatan intermolekular [6].
Pembuatan bioplastik berbasis pati pada dasarnya menggunakan prinsip gelatinisasi. Dengan adanya penambahan sejumlah air pada pati dan dipanaskan pada suhu yang tinggi, maka granula patinya akan menyerap air dan membengkak, inilah yang disebut proses gelatinisasi. Namun demikian jumlah air yang terserap dan pembengkakannya terbatas. Pati dapat menyerap air secara maksimal jika suspensi air dipanaskan pada temperatur $55^{\circ} \mathrm{C}$ sampai $65^{\circ} \mathrm{C}$. Suhu gelatinisasi pati mempengaruhi perubahan viskositas larutan pati, dengan meningkatnya suhu pemanasan mengakibatkan penurunan kekentalan suspensi pati. Suhu pada saat granula pati pecah disebut suhu gelatinisasi [16]. Gelatinisasi mengakibatkan ikatan amilosa akan cenderung saling berdekatan karena adanya ikatan hidrogen. Setelah terjadi proses gelatinisasi, kemudian larutan gelatin dicetak atau dituangkan pada tempat pencetakan dan dikeringkan selama 24 jam. Proses pengeringan akan mengakibatkan penyusutan sebagai akibat dari lepasnya air, sehingga gel akan membentuk bioplastik yang stabil [4].

\section{Metodologi Penelitian}

Dalam proses pembuatan bioplastik metode yang dipakai yakni metode casting [4]. Terlebih dahulu dilakukan proses pembuatan pati. Proses pembuatan pati umbi talas diawali dengan cara 100 gr umbi talas dicuci dengan air biasa kemudian ditiriskan. Umbi talas dikuliti dengan pisau kemudian dipotong berbentuk kubus berukuran kira-kira $\left(\begin{array}{lllll}1 & \mathrm{x} & 1 & \mathrm{x} & 1\end{array}\right) \mathrm{cm}$. Umbi talas tersebut dimasukkan kedalam blender dan ditambahkan dengan air sebanyak $100 \mathrm{ml}$ lalu diblender hingga halus. Hasil blender kemudian disaring dengan menggunakan saringan biasa. Filtrat yang diperoleh didiamkan selama 24 jam hingga terbentuk endapan (pati). Air dibuang untuk mendapatkan endapan pati. Endapan pati dicuci dengan menambahkan air pada pati tersebut, diaduk, lalu biarkan 1 jam lalu dibuang airnya. Diulangi kembali dengan menambahkan air pada endapan pati hingga diperoleh endapan pati yang benar - benar bersih. Hasil endapan pati yang diperoleh kemudian dimasukkan ke dalam beaker untuk dikeringkan dengan oven pada temperatur $80^{\circ} \mathrm{C}$ selama 15 menit.

Hasil pati kering dari umbi talas dapat dilihat pada Gambar 1. Larutan pati 0,2 w/v dimasukkan kedalam beaker gelas, kemudian ditambahkan 2 $\mathrm{ml} \mathrm{CH}_{3} \mathrm{COOH}$ Glasial. Kedalam campuran ditambahkan gliserol sebanyak $1 \% \mathrm{v}$ dan diaduk sampai homogen. Larutan kemudian dipanaskan pada hot plate dengan temperatur mencapai $70^{\circ} \mathrm{C}$ 
sambil diaduk dengan batang pengaduk hingga terjadi gelatinisasi. Larutan tersebut kemudian dituangkan ke cetakan $25 \mathrm{~cm} \mathrm{x} 25 \mathrm{~cm}$ x $1 \mathrm{~mm}$ lalu di dikeringkan pada suhu kamar selama 24 jam. Setelah itu hasilnya dianalisa.

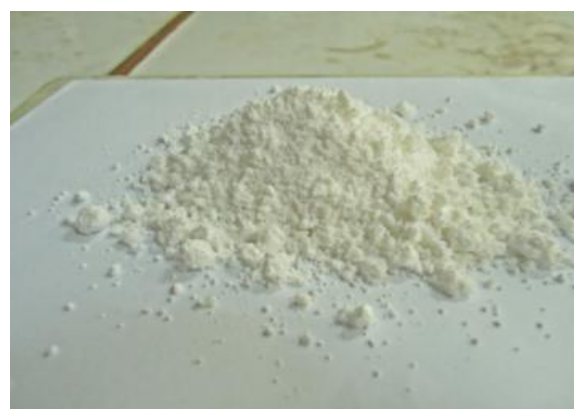

Gambar 1. Pati Kering dari Umbi Talas

Bioplastik yang dihasilkan diuji sifat mekanikalnya seperti sifat kekuatan tarik dan sifat pemanjangan saat putus dengan menggunakan alat autograph-shimadzu berdasarkan ASTM D882. Dilakukan juga pengujian FTIR (Fourier Transform Infrared Spectroscopy) dengan menggunakan alat Shimadzu IR pada pati umbi talas dan bioplastik yang dihasilkan yang bertujuan untuk mengetahui gugus fungsi yang ada pada pati umbi talas dan bioplastik. Dan untuk mengetahui sifat bioplastik maka dilakukan analisa morfologi SEM (Scanning Electron Microscope) dengan menggunakan alat JSM 6360.

\section{Hasil dan Pembahasan}

Bioplastik yang dihasilkan pada penelitian ini berwarna bening. Bioplastik setelah pengeringan dapat dilihat pada Gambar 2.

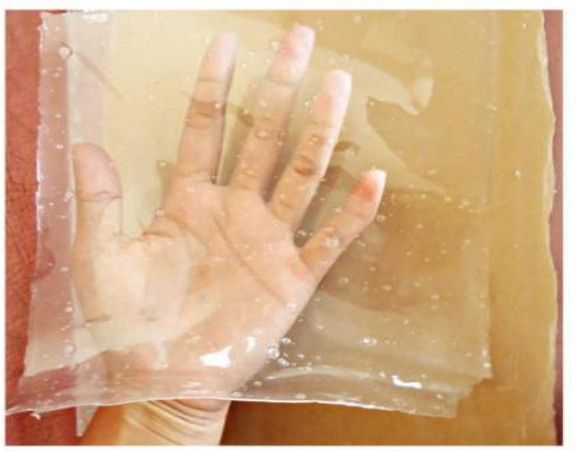

Gambar 2. Bioplastik setelah Pengeringan

Untuk menentukan kualitas bioplastik parameter yang dipakai adalah sifat mekanikal bioplastik yang terdiri dari sifat kekuatan tarik (tensile strength) dan sifat pemanjangan saat putus (elongation break).

\section{Pengaruh Penambahan Gliserol terhadap Sifat Kekuatan Tarik Bioplastik}

Pengaruh penambahan gliserol terhadap sifat kekuatan tarik bioplastik dapat dilihat pada gambar 3 .

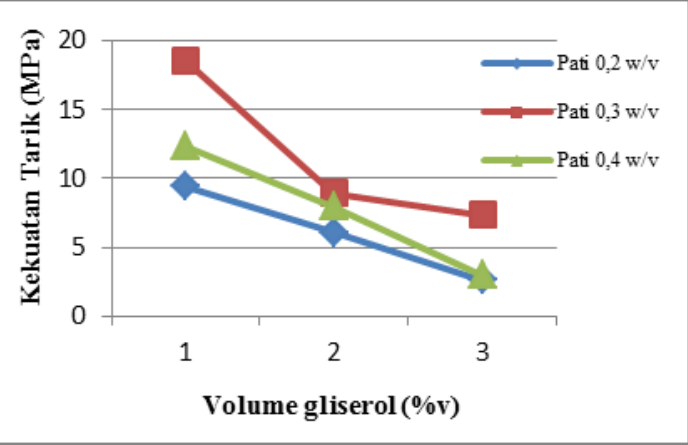

Gambar 3. Pengaruh Penambahan Gliserol terhadap Sifat Kekuatan Tarik Bioplastik

Gambar 3 menunjukkan semakin banyak gliserol yang ditambahkan maka sifat kekuatan tariknya akan semakin rendah, tetapi jika gliserol yang ditambahkan terlalu sedikit maka bioplastik yang dihasilkan akan mudah mengalami keretakan/kurang elastis. Nilai kekuatan tarik terendah adalah pada pati $0,2 \mathrm{w} / \mathrm{v}$, penambahan $3 \%$ v gliserol dengan nilai kekuatan tarik 1,7583 $\mathrm{MPa}$ dan nilai kekuatan tarik tertinggi adalah pada pati $0,3 \mathrm{w} / \mathrm{v}$, penambahan $1 \% \mathrm{v}$ gliserol dengan nilai kekuatan tarik 18,4992 MPa.

Penambahan gliserol dapat menurunkan kekuatan intermolekuler bioplastik diantara rantai polimer dan meningkatkan fleksibilitas bioplastik [7]. Hasil pengujian tersebut juga menunjukkan hal yang sama dengan penelitian yang dilakukan oleh Bayu (2008), penelitian yang dilakukan yaitu pembuatan edible film dari kitosan dengan gliserol sebagai plasticizer. Nilai kekuatan tarik pada gliserol 0,2 (ml/gr), 0,4 (ml/gr), 0,6 (ml/gr) berturut adalah sebesar $111,130 \mathrm{kgf} / \mathrm{cm}^{2}, 51,334 \mathrm{kgf} / \mathrm{cm}^{2}$, dan 37,554 $\mathrm{kgf} / \mathrm{cm}^{2}$. Semakin banyak plasticizer (pemlastis) yang ditambahkan maka kekuatan tarik akan berkurang [2].

\section{Pengaruh Penambahan Gliserol terhadap Sifat Pemanjangan Saat Putus Bioplastik}

Pengaruh penambahan gliserol terhadap sifat pemanjangan saat putus bioplastik dapat dilihat pada gambar 4 . 


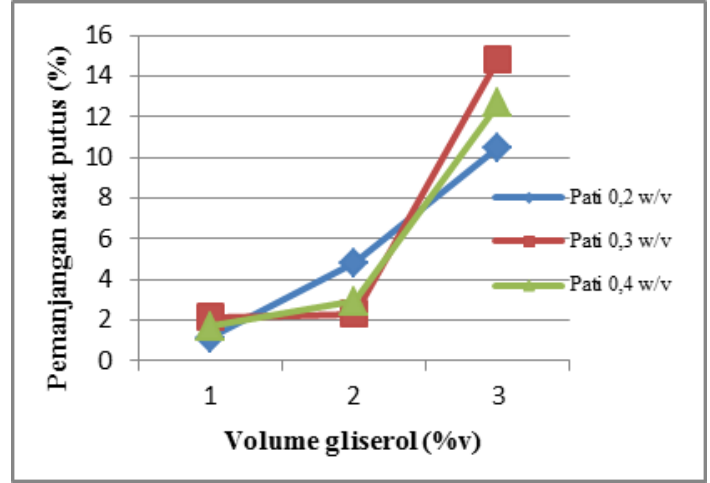

Gambar 4. Pengaruh Penambahan Gliserol terhadap Sifat Pemanjangan Saat Putus Bioplastik

Gambar 4 menunjukkan semakin banyak gliserol yang ditambahkan maka sifat pemanjangan saat putusakan semakin tinggi, tetapi jika gliserol yang ditambahkan terlalu sedikit maka bioplastik yang dihasilkan kurang elastis. Nilai pemanjangan saat putus terendah pada pati $0,2 \mathrm{w} / \mathrm{v}$, penambahan $1 \% \mathrm{v}$ gliserol dengan nilai pemanjangan saat putus $2,1290 \%$ dan mengalami peningkatan nilai pemanjangan saat putus tertinggi pada pati $0,3 \mathrm{w} / \mathrm{v}$, penambahan $3 \quad \% \quad \mathrm{v}$ gliserol dengan nilai pemanjangan saat putus $14,8448 \%$.

Penambahan gliserol akan meningkatkan mobilitas molekuler rantai polimer yang ditunjukkan dengan bioplastik semakin elastis sehingga perpanjangan saat putus cenderung akan meningkat [15]. Hasil pengujian tersebut juga menunjukkan hal yang sama dengan penelitian yang dilakukan oleh Bayu (2008), nilai pemanjangan saat putus yang diperoleh pada penambahan gliserol $0,2,0,4,0,6(\mathrm{ml} / \mathrm{gr})$ secara berturut adalah $5,20 \%, 2,8534 \%$, dan $2,8649 \%$.

\section{Karakteristik Hasil Analisa FTIR}

Hasil FTIR pati umbi talas dan bioplastik ditampilkan pada gambar 5 dan 6 .

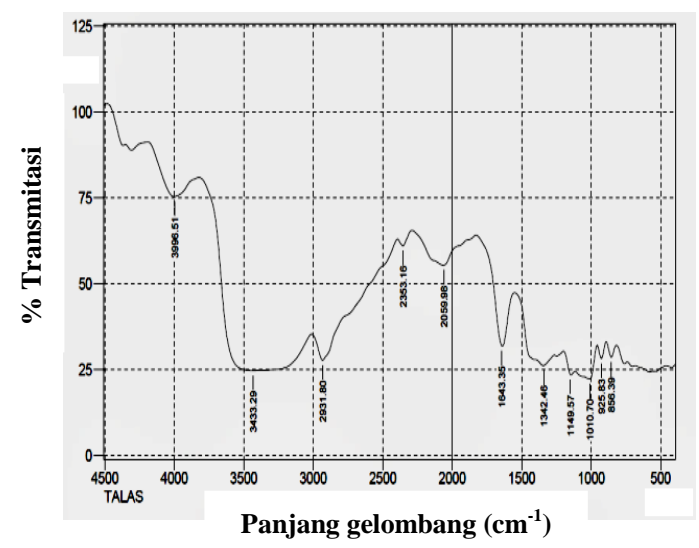

Gambar 5. Karakteristik Hasil Analisa FTIR Pati Umbi Talas

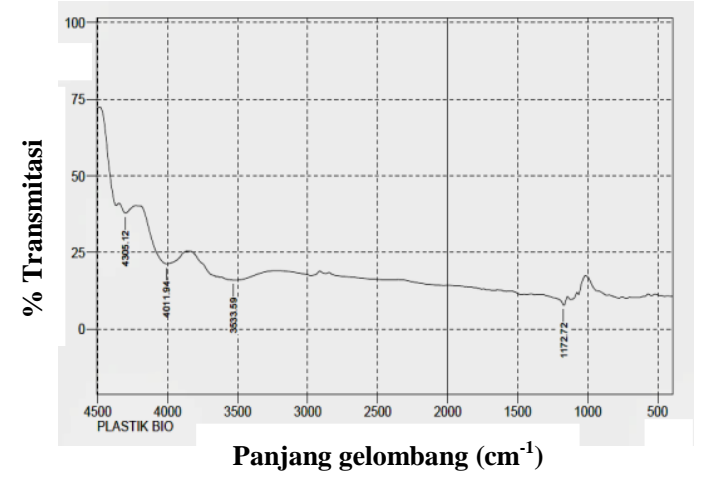

Gambar 6. Karakteristik Hasil Analisa FTIR Bioplastik Pati 0,3 w/v, Penambahan $1 \%$ Gliserol, dan Temperatur Gelatinisasi $70^{\circ} \mathrm{C}$

Tabel 2. Karakteristik Hasil Analisa FTIR Pati Umbi Talas [8]

\begin{tabular}{|l|c|}
\hline \multicolumn{1}{|c|}{ Daerah Penyerapan } & $\begin{array}{c}\text { Frekuensi } \\
\left(\mathbf{c m}^{-1}\right)\end{array}$ \\
\hline Pati Umbi Talas \\
\hline Vibrasi regang O-H dan N-H & $3700-3100$ \\
\hline Vibrasi regang C-H & $3200-2850$ \\
\hline Vibrasi ikatan ganda dua & $1950-1550$ \\
\hline $\begin{array}{l}\text { Vibrasi regang ikatan ganda } \\
\text { tanpa C }\end{array}$ & $1400-1300$ \\
\hline $\begin{array}{l}\text { Vibrasi senyawa aromatik, } \\
\text { lentur C-H didalam bidang }\end{array}$ & $1300-1000$ \\
\hline $\begin{array}{l}\text { Vibrasi senyawa aromatik, } \\
\text { lentur C-H diluar bidang }\end{array}$ & $900-600$ \\
\hline Bioplastik Pati Umbi Talas \\
\hline Vibrasi regang O-H dan N-H & $3700-3100$ \\
\hline $\begin{array}{l}\text { Vibrasi senyawa aromatik, } \\
\text { lentur C-H didalam bidang }\end{array}$ & $1300-1000$ \\
\hline
\end{tabular}

Dilakukan penggabungan grafik untuk melihat perbedaan yang terjadi antara pati umbi talas dan bioplastik.

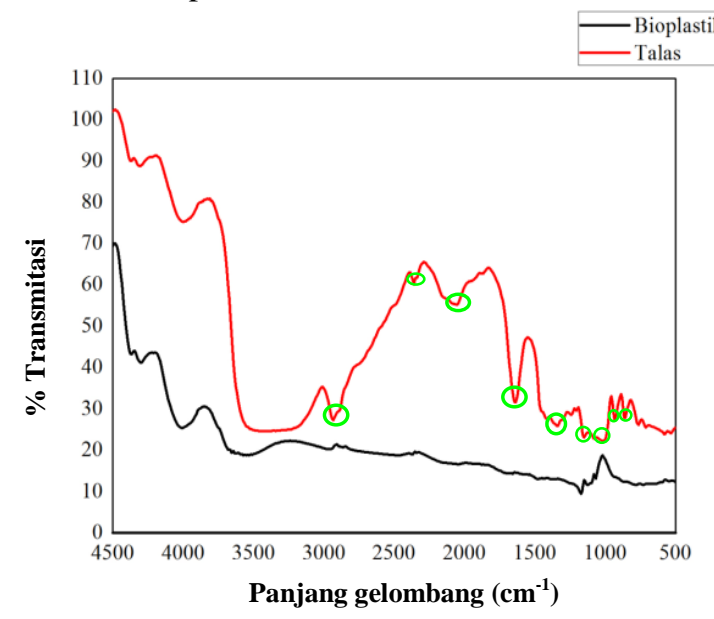

Gambar 7. Karakteristik Hasil Analisa FTIR Pati Umbi Talas dan Bioplastik Pati 0,3 w/v, Penambahan $1 \%$ v Gliserol, dan Temperatur Gelatinisasi $7^{\circ} \mathrm{C}$ 
Gambar 7 menunjukkan seluruh spektrum bioplastik pati $0,3 \mathrm{w} / \mathrm{v}$, penambahan $1 \% \mathrm{v}$ gliserol dan temperatur gelatinisasi $70^{\circ} \mathrm{C}$ berada dibawah spektrum pati talas. Spektrum pati talas berbeda dengan spektrum bioplastik dikarenakan ada beberapa gugus fungsi yang hilang. Pada pati talas mempunyai vibrasi regang $\mathrm{C}-\mathrm{H}$, ikatan ganda dua, regang ikatan tanpa $\mathrm{C}$ yang didiagnostik $\mathrm{O}=\mathrm{N}$ dan lentur $\mathrm{CH}$ dalam bidang sedangkan pada bioplastik tidak terdapat lagi vibrasi seperti pada talas yang dikarenakan proses gelatinisasi yang memutuskan monomermonomer yang terkandung pada talas.

\section{Analisa Morfologi}

Analisa morfologi SEM merupakan suatu metode untuk membentuk bayangan daerah mikroskopis permukaan sampel[5]. Bioplastik yang diuji adalah bioplastik dengan nilai kekuatan tarik tertinggi yaitu 18,4992 MPa pada variasi pati $0,3 \mathrm{w} / \mathrm{v}$ dengan penambahan gliserol $1 \%$ v. Hasil SEM ditunjukkan pada gambar 8 .

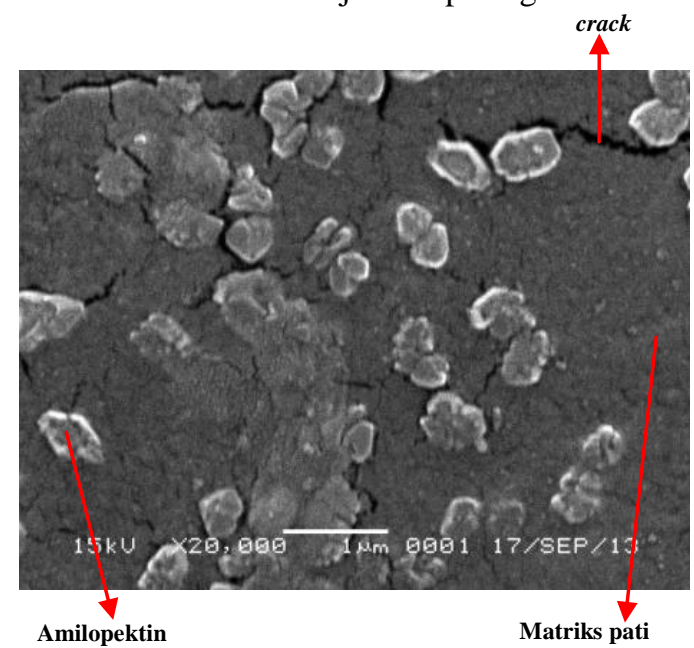

Gambar 8. Hasil SEM Bioplastik (perbesaran 20000X)

Proses analisa SEM menghasilkan elektron yang difokuskan menuju sampel, ketika elektron mengenai sampel maka sampel akan mengeluarkan pantulan elektron baru. Pantulan elektron tersebut menghasilkan sinyal backscattered electron yang secara prinsip, atom-atom dengan berat molekul lebih besar akan memantulkan lebih banyak elektron sehingga tampak lebih cerah dari atom dengan berat molekul rendah. Di dalam matriks sampel, atom yang memiliki berat molekul terbesar adalah amilopektin [12]. Amilopektin memiliki berat molekul \pm 500.000 sedangkan amilosa memiliki berat molekul 40.000-150.000 [13].

Gambar 8 hasil SEM bioplastik dengan perbesaran 20000 kali, morfologi permukaan atas terlihat adanya crack berwarna hitam yang menunjukkan retakan diduga terjadi karena ukuran amilopektin masih terlalu besar. Ukuran amilopektin yang masih besar mengakibatkan tidak rapatnya partikel amilopektin pada matriks pati, yang ditunjukkan dengan lempenganlempengan berwarna putih yang tidak larut sempurna.

\section{Kesimpulan}

Penambahan volume gliserol berpengaruh terhadap nilai kekuatan tarik (tensile strength) dan pemanjangan saat putus (elongation break) dari bioplastik yang dihasilkan. Seiring bertambahnya volume gliserol maka nilai kekuatan tarik akan semakin menurun, sebaliknya nilai pemanjangan saat putus akan semakin meningkat.

Bioplastik berbahan baku umbi talas yang terbaik pada penelitian ini adalah bioplastik variasi larutan pati $0,3 \mathrm{w} / \mathrm{v}$, penambahan $1 \% \mathrm{v}$ gliserol pada temperatur $70^{\circ} \mathrm{C}$ dengan nilai kekuatan tarik $18,4992 \mathrm{MPa}$ dan nilai pemanjangan saat putus $2,1290 \%$.

Dari hasil analisi FTIR, spektrum pati umbi talas berbeda dengan spektrum bioplastik yang dihasilkan dikarenakan ada beberapa gugus fungsi yang hilang. Hasil analisa SEM bioplastik menunjukkan amilopektin tidak rapat dalam matriks pati.

\section{Daftar Pustaka}

[1] Banggawan, Sulit Terurai, Indonesia Butuh Alternatif Plastik. Inilah.com, Jakarta, 2012.

[2] Bayu, Pengaruh Konsentrasi Plasticizer Gliserol dan Komposisi Kitosan dalam Zat Pelarut terhadap Sifat Fisik Edible Film dari Kitosan, Universitas Indonesia, Jakarta, 2008.

[3] Bourtoom, Edible films and coatings: Characteristics and properties, Department of Material Product Technology, Prince of Songkla University, Thailand, 2007.

[4] Careda, et al, Classification of Cassava Starch Films by Physicochemical Properties and Water Vapor Permeability Quantification by FTIR and PLS, 2007.

[5] Edo, Sintesis Bioplastik dari Pati Ubi Jalar Menggunakan Penguat Logam $\mathrm{ZnO}$ dan Penguat Alami Selulosa, Universitas Indonesia, Depok, 2012.

[6] Kirk dan Othmer, Encyclopedia of Chemical Technology, Volume 12, Fourth Edition, John Wiley \& Sons Inc. New York, 1967.

[7] Latief, Teknologi Kemasan Plastik Biodegradable, Makalah Falsafah Sains 
(PPs 702) Program Pasca Sarjana /S3 Institut Pertanian Bogor, Bogor, 2001.

[8] Noerdin,Daslin, Eluisidasi Struktur Senyawa Organik dengan Cara Spektroskopi Ultralembayung dan Inframerah, Penerbit Angkasa, Bandung, 1985.

[9] Pranamuda, Pengembangan Bahan Film Plastik Berbahan Baku Pati Tropis, Hasil Penelitian dari Badan Pengkajian dan Penerapan Teknologi, Jakarta, 2003.

[10] Prihatman, Kemal, Talas (Colocasia esculenta), Sistim Informasi Manajemen Pembangunan di Perdesaan, Proyek Pengembangan Ekonomi Masyarakat Daerah (PEMD) BAPPENAS, Jakarta, 2000.

[11] Pusat Pendidikan Lingkungan Hidup, Bahaya Bahan Plastik, Seloliman, Tawas, Mojokerto, 2007.

[12] Rapuan, Mandeleyev, Scanning Electron Microscope (SEM), Makassar, 2008.

[13] Samsuri, Bilal, Penggunaan Pragelatinisasi Pati Singkong Suksinat sebagai Matriks dalam Sediaan Tablet Mengapung Verapamil Hcl, Universitas Indonesia, Jakarta, 2008.

[14] Syamsir, Elvira, Talas, Andalan Bogor, Institut Pertanian Bogor, 2012.

[15] Syamsu, Khaswar, dkk., Karakteristik Bioplastik Poli- $\beta$-hidroksialkanoat yang Dihasilkan oleh Ralstonia eutropha pada Substrat Hidrosilat Pati Sagu dengan Pemlastis Isopropil Palmitat, Jurnal Teknologi Pertanian Universitas Mulawarman, ISSN 1858-2419 Vol. 3 No. 2, Samarinda, 2008.

[16] Winarno, Kimia Pangan dan Gizi, Gramedia, Jakarta, 1992. 